\title{
Cradle-to-Gate Life Cycle Assessment of Pineapple Leaf Fibres
}

\section{An alternative to non-biodegradable PPE base materials}

\author{
Putri Rizky Salsabila ${ }^{1, *}$ Altair Boonraksa ${ }^{2,}$ Innamia Indriani ${ }^{3,}$ Sabrina Ilma \\ Sakina ${ }^{4}$, Benno Rahardyan ${ }^{5}$
}

${ }^{1}$ Institut Teknologi Bandung, Indonesia

${ }^{2}$ Institut Teknologi Bandung, Indonesia

${ }^{3}$ Institut Teknologi Bandung, Indonesia

${ }^{4}$ Institut Teknologi Bandung, Indonesia

${ }^{5}$ Institut Teknologi Bandung, Indonesia

${ }^{*}$ Corresponding author. Email: putrirzkysbl@students.itb.ac.id

\begin{abstract}
As the COVID-19 pandemic emerged in Indonesia, there had been a steep increase in the need for personal protective equipment (PPE). This phenomenon left a directly proportional yield in solid waste production by $30-$ $50 \%$, generating a total of $1,662.75$ tons as of October 2020 . However, the capacity of medical waste treatment facilities is still limited. Disposable PPE base material generally comes from polymer blends with a degradation period of hundreds of years. One potential alternative for disposable PPE base material is pineapple leaf fibre. Pineapple leaves are a pineapple by-product. In 2018, pineapple production in Indonesia reached 1.81 million tons. Pineapple leaf fibre has a tensile strength of $2.21 \mathrm{kN} / \mathrm{m}$ and cellulose content of $70-80 \%$ making its resistance similar to polymer but with a soil degradation period of about 21 days. This study is an open-ended review aiming to compare the resulting impact of the disposable PPE base material surrogated by pineapple leaf fibre. The Life Cycle Assessment (LCA) method is applied to analyse carbon footprint in the cradle-to-gate coverage, with the cradle as the harvest and the gate as the ready-to-ship product. The results of this study can open up various research opportunities regarding other LCAs for the production of fabrics made from pineapple leaf fibre and other applicable natural materials to reduce the period of degradation of medical waste.
\end{abstract}

Keywords: LCA, disposable PPE, pineapple leaf fibre.

\section{INTRODUCTION}

In response to COVID-19, WHO (2020) estimates the need for 89 million medical masks, 76 million examination gloves, and 1.6 million goggles every month. Thus, increasing the demand for manufacturers to supply PPE by $40 \%$ to accommodate the medical community [1]. Consequently, the massive increment leads to the immense production of medical waste [2].

In Indonesia, the Ministry of Environment and Forestry stated that medical waste had increased by $30 \%-50 \%$ during the pandemic and was ranked the 9 th largest medical waste-producing country, which was
420.03 tons/day [3]. The medical waste is not treated according to applicable regulations and is even thrown away and pollutes the environment. The capability of medical waste management in developing countries is only processed as much as $20 \%$. It is precarious for the environment [4]. The obstacle in transporting medical waste in Indonesia is the scattered data location of self-isolated patients making transportation of medical waste has the potential to be mixed with other household waste [5]. The results of research in the Cilincing and Marunda river estuaries found that PPE waste was $15-16 \%$ of the total netted waste [6]. In addition, the results of a study in Padang, West Sumatra proved that $75.9 \%$ of high-income household 
respondents disposed of medical masks and mixed them with other waste, $6.02 \%$ of respondents dispose of medical waste in separate places, and $18.07 \%$ of respondents cut it before throwing it away. As many as $100 \%$ of low-income household respondents dispose of masks along with other waste. It proves the lack of public knowledge about the processing and hazards of medical waste [7]. The transportation of household medical waste should use a distinct vehicle for transporting medical waste along with disinfecting it using $1 \%$ sodium hypochlorite solution after each use [8].

The basic materials used for PPE are generally more than $50 \%$ of a mixture of polymers and other types of plastics such as PVC and PC, so they have a degradation time of up to 500 hundred years [9]. One of the effective disinfecting final treatment methods for medical waste is to use an incinerator with a minimum temperature of $850{ }^{\circ} \mathrm{C}$ for 60 minutes. However, the treatment of most PPE waste made from polypropylene (PP) using an incinerator raises pros and cons [3]. Although considered effective for destroying waste, burning PP at high temperatures can produce harmful gas particles, including greenhouse gas emissions (GHG) which have an impact on Global Warming Potential (GWP) [2]. In addition, PP combustion also produces dioxin and furan gas particles that can accumulate in human tissues and affect health. Ultimately, this pandemic highlights the urgent need for more environmentally friendly and health-safe material solutions for disposable equipment [10]. Seeing this situation, finding an alternative for PPE-based materials is essential to reduce PP waste. One of the most potent materials having a similar resistance to $\mathrm{PP}$ comes from pineapple leaf fibre (PALF), considering pineapple plantations prevail in various countries, including Indonesia. Pineapple Leaf Fibres (PALF) has a tensile strength of $2.21 \mathrm{kN} / \mathrm{m}$ and $70-80 \%$ cellulose, making it similar to PP.

With the availability of alternative resources, a Life Cycle Assessment (LCA) serves as one of the methods of environmental impact assessment. LCA studies environmental aspects and potential impacts throughout the product's life from start to finish (cradle-to-grave), i.e., raw material acquisition to production, use, and disposal. Environmental impact variables to consider include resource use, human health, and ecological consequences [11]. Therefore, an LCA about polypropylene and a non-woven PALF as PPE base material can provide more insight into environmental aspects in a comparative context. Furthermore, LCA alleviates the differences resulting from the environmental impacts of different product formulations [12]. Analysis using LCA can determine system boundaries and study coverage as needed [13]. Life Cycle Assessment cradle-to-gate of polypropylene and non-woven PALF as PPE base material in this study focused on carbon footprint analysis to provide substantial guidance in identifying impacts and environmentally friendly alternatives.

\subsection{Literature Study}

\subsubsection{Polypropylene (PP)}

Polypropylene (PP) is a downstream petrochemical product derived from the olefin monomer propylene. Production of PP went through an additional polymerization process, which combines monomers using heat, high energy radiation, and an initiator or catalyst. The polymerization of propylene molecules turns into very long polymer molecules or chains. Polypropylene is a lightweight polymer with a density of $0.90 \mathrm{~g} / \mathrm{cm} 3$, making it suitable in many industrial applications. PP offers low production costs and good strength. A common variation of PP usage is nonwoven textiles, often used as the primary material for disposable PPE, bags, clothes, etc. Massive production, especially the increasing need for PPE during the COVID-19 pandemic, is in line with the amount of waste generated. However, polypropylene is not suitable for use at temperatures below $0^{\circ} \mathrm{C}$ [18]. These plastics contain additives, including dyes, plasticizers, and stabilizers (mainly cadmium and lead) [14]. Generally, waste polypropylene (PP) takes 20-30 years to degrade completely [15]. At high temperatures, the material will decompose and produce smoke containing $\mathrm{CO}_{2}$, CO, Ketones \& Aldehydes [16].

\subsubsection{Pineapple Leaf Fibres (PALF)}

Some areas in Indonesia that are famous for the cultivation of pineapple plants are Sumatra and Java. There is pineapple cultivation with the Smooth Cayenne variety on Java, precisely in the Subang Regency [17]. Subang Regency is the largest pineapple-producing center in Indonesia. According to the Central Bureau of Statistics of Subang Regency (2020), in 2019, the number of pineapple fruit production in Subang reached 266,720.3 tons, more significant than other fruit production. Many 500 families depend on pineapple farming for their income, with an average plantation land ownership of $0.4 \mathrm{Ha}$, but farmers only focus on pineapple production without processing. Generally, agricultural products produce $30-40 \%$ of waste materials that can be processed to produce added value [18]. The amount 
of pineapple leaf waste in the field reaches 60 tons per hectare [19].

The Smooth Cayenne variety accounts for $70 \%$ of world pineapple production [20] due to its high quality and stress tolerance [21]. The Smooth Cayenne variety is not very suitable for export because it has a relatively short shelf life and is susceptible to various post-harvest pests and diseases. The ideal temperature range for its cultivation is $18-32{ }^{\circ} \mathrm{C}$. This variety is drought tolerant but not water tolerant, and the soil medium must be loose to a depth of at least $60 \mathrm{~cm}$ with a pH range of 4.5-6.5. Smooth Cayenne can grow with high rainfall, i.e., $635-2500 \mathrm{~mm}$ per year, but the optimal annual rainfall for commercial production ranges from 1000-1500 $\mathrm{mm}$ [22].

PALF is considerably a good substitute for synthetic fibres because it is economical and renewable. The superior mechanical properties of PALF are related to its high alpha-cellulose content and low microfibrillar angle $\left(14^{\circ}\right)$. PALF's outstanding qualities are making it suitable as a composite matrix reinforcement. The results of PALFbased polymer composites showed excellent stiffness and strength compared to other cellulose-based composite materials [23]. The wet PALF bundle characteristics show lower strength by $50 \%$, but the strength increases by up to $13 \%$ when converted into yarn. PALF exhibits a modulus range from 34.5 to $82.51 \mathrm{GN} \cdot \mathrm{m}-2$, tensile strength ranges from 413 to $1627 \mathrm{MN} \cdot \mathrm{m}-2$, and elongation at breakpoint ranges from 0.8 to $1.6 \%$. PALF has been widely used in automobiles, textiles, mats, construction, and so on [25].

\subsubsection{PALF Paper (Nonwoven Textiles)}

Polypropylene (PP) is a downstream petrochemical product derived. PALF has a high fibre strength [24] compared to other natural fibres and potentially be an environmentally friendly PP alternative material. This textile manufacture utilizes paper-making methods from pulp to printing, with almost no additional chemicals as adhesives [17]. The requirement naturally ourred within the composition of PALF, which contains $4.2 \%$ lignin and $80 \%$ cellulose as parameters to determine the strength and suitability of fibres in paper (nonwoven textiles) manufacture. High cellulose content will increase fibre strength and paper quality [26], while low lignin content will facilitate the removal of pulp so that the resulting paper has a high quality [27]. PALF nonwoven textiles have good breathability so that they can filter out small particles more remarkably [28]. In addition, the cost is lower (because it is a byproduct of agricultural products). Many PPEs consist of nonwettable materials, particularly those with a spunbond melt-spun spun-bond (SMS) laminate, which makes them less breathable and can cause sweating of the covered areas of the body. In this case, alternative PPE materials are needed that are suitable, durable but with better air circulation, and can dry out if exposed to wet [29]. However, the main weakness of PALF is its hydrophilic nature, i.e., the water absorption rate is relatively high. As a material that can be an alternative to polypropylene, PALF still needs to be developed to find a suitable matrix to change its surface properties. For example, based on the research of Samal and Ray (1997), surface modification by chemicals such as sodium hydroxide $(\mathrm{NaOH}), 2$,4-dinitrochlorobenzene, benzoyl peroxide (BPO), and $\mathrm{BPO} /$ acetylation can minimize water absorption and improve the mechanical properties of PALF [30].

The study uses exploratory pulp and papermaking methods with the essential ingredients of the PALF Smooth cayenne variety obtained from pineapple plantations in Cijambe. According to BPS data (2020), a garden with a land area of 300 ha can produce 1205.9 tons of pineapple per year. This production level is the ideal amount for the utilization of pineapple leaf waste. In this processing, pineapple leaves ' $\mathrm{C}$ ' and ' $\mathrm{D}$ ' are used as prime leaf categories with a length of over $65 \mathrm{~cm}$ and have the best nutritional and fibre content for one life cycle-pineapple [31].

Processing of PALF into nonwoven textiles with the paper-making technique requires adding the chemical teepol in the scouring process and sodium hydroxide $(\mathrm{NaOH})$ in the softening process [17]. The tools needed are stove, container, scissors, blender, screen, and rack. PALF goes through a scouring process at the initial stage that aims to soften and clean PALF from dirt and other congenital substances. The process includes boiling the leaf fibre for 40 minutes in 2.5 liters of water $(\mathrm{w} / \mathrm{v})$ and adding $12 \%(\mathrm{v} / \mathrm{v})$ of teepol. The fibre is then cut into pieces of $10 \mathrm{~cm}$ to aid the pulverization process when boiled with sodium hydroxide as much as $33 \%$ by weight of the fibre with an interval of 1 hour boiling time. The boiled fibre is then mixed with water in a blender until the fibre becomes pulp.

The pulverized fibre (pulp) is stored in a tub and mixed with water in a ratio of 1:3 (fibre:water), inserting the screen into the tub to print the pulp and then lifting the screen from the tub to carry out its attached fibres. The screen and the attached fibres are dried in the open air to dry. Variations in thickness and texture can be adjusted by transferring the fibre on the screen's surface to a wooden board or plywood and 
leveling it using a racket. After it is dried, using the IT9500 heat press machine to make the paper compact. $1 \mathrm{~kg}$ of pineapple leaf fibre with a specific gravity of $0.8822 \mathrm{~g} / \mathrm{cm}^{3}$ can be processed into $1.5 \mathrm{~m}^{2}$ of material with a thickness of $381.5 \mu \mathrm{m}$ with a tensile strength of $2.21 \mathrm{kN} / \mathrm{m}$ [32].

The resulting paper performs a strong bond even with various thicknesses. The thicker the paper print, the less water it will absorb. Factors that affect the pulp condition include chemical levels, the type of chemical used must be highly alkaline, and the boiling time interval [17]. PALF paper making in this study did not use an additional cementing matrix [27].

\subsubsection{Carbon Footprint Inventory}

Verification of the number of carbon emissions and fuel use from primary data obtained through previous research. The study uses equivalence to simplify the calculation

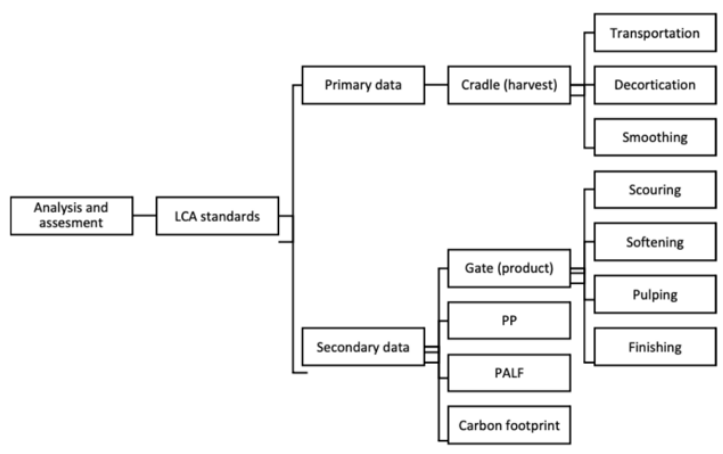

Figure 1 Method.

\subsection{Goal and Scope}

This research is an open-ended study aimed at opening up opportunities related to using pineapple leaf waste as an alternative textile material. The scope of the "cradle-to-gate" study focuses on the papermaking process (nonwoven textiles) from PALF, from taking pineapple leaves at the Cijambe pineapple

Table 1. Carbon footprint inventory

\begin{tabular}{|c|ll|l|l|l|}
\hline No. & Items & Emissions & Units & Source \\
\hline 1 & Diesel & 2.68 & $\mathrm{Kg} \mathrm{CO}_{2}$ eq./L Solar & Exeter.ac.uk \\
\hline 2 & $\mathrm{PP}$ & 4.77 & $\mathrm{Kg} \mathrm{CO}$ eq./kg PP & Korol, et al., 2020 \\
\hline 3 & $\begin{array}{c}\text { Sodium } \\
(\mathrm{NaOH})\end{array}$ & hydroxide & 0.6329 & $\begin{array}{l}\mathrm{Kg} \mathrm{CO} \quad \text { eq./kg } \\
\mathrm{NaOH}\end{array}$ & $\begin{array}{l}\text { Thannimalay, L. et } \\
\text { al., 2013 }\end{array}$ \\
\hline 4 & $\begin{array}{c}\text { Sodium } \\
\left(\mathrm{Na}_{2} \mathrm{CO}_{3}\right)\end{array}$ & Carbonate & 1.84 & $\begin{array}{c}\mathrm{Kg} \mathrm{CO} \quad \text { eq./kg } \\
\mathrm{Na}_{2} \mathrm{CO}_{3}\end{array}$ & $\begin{array}{l}\text { Prashantsinh, M. et } \\
\text { al., 2015 }\end{array}$ \\
\hline
\end{tabular}

\section{METHODOLOGY}

\subsection{Methodology}

This research uses the Life Cycle Assessment (LCA) methodology with a quantitative process that allows the understanding and assessing of the magnitude and significance of environmental impacts based on the results obtained from the analysis of the inventory.

Method:

a. Procuring standards, secondary data to support equivalence

b. Primary data to assess carbon footprint

c. Analysis and assessment plantation to making $1 \mathrm{~m}^{2}$ paper products. This study uses a comparison of the carbon footprint produced to make a nonwoven textile measuring $1 \mathrm{~m}^{2}$ using PALF and polypropylene (PP). Raw materials obtained from previous studies show the comparison of carbon emissions produced during the manufacturing process and the natural degradation time required [33]. Within this LCA study, the author limits the scope to carbon footprint calculation covering the process since the pineapple leaves harvest until the ready-to-use product in the form of $1 \mathrm{~m}^{2}$ nonwoven textile.

\subsection{Standards and Data}

Primary data consists of making PALF from harvest to PALF kilos, and the preceding journal is the number of $\mathrm{kg}$ of carbon emissions produced, according to the functional unit obtained from historical data of the Alfiber company through interviews with company owners and employees at the production site. Verification of the number of carbon 
emissions and fuel use from primary data obtained through previous research. Historical primary data related to procedures and best practices of PALF production were collected and modified over time since 2013.

The secondary data for PALF paper-making was acquired from previous research, part of the study team [17]. The polypropylene (PP) material in PPE is inclusive in the type of nonwoven textile. Therefore, PP material is compared with alternative PALF materials also processed into nonwoven textiles using paper-making techniques. Paper printing and packaging of $1 \mathrm{~m}^{2}$ is manually operated.

The primary and secondary data obtained are then processed through Microsoft Excel, including the amount of carbon produced, the density of the material, and the conversion of functional units according to the predetermined boundary.

The study analysis uses the guidance according to ISO 14040 and 14044 (ISO, 2006). The guidebooks used are Life Cycle Assessment (LCA): A Guide to Best Practice by Walter Klopffer and Birgit Grahl, 2014 and Life Cycle Assessment: Theory and Practice by Michael Z. Hauschild, Ralph K. Rosenbaum, Stig irving Olsen.

The inventory table modeling with element removal at the system boundary refers to the standard set by SETAC in 1990/1991. The determination of the functional unit refers to the guidelines contained in in Cijambe District. The temporal System Boundary allowance for data needs with a tolerance of 5 years.

\section{RESULTS}

This study shows a comparison of the carbon footprint of the manufacture of $1 \mathrm{~m}^{2}$ of nonwoven fabric made from PALF at a private production site in Subang, West Java, compared to the manufacture of $1 \mathrm{~m}^{2}$ of nonwoven fabric made from PP fabrication. The PALF production site has an area of $8.5 \times 17 \mathrm{~m}$, located in the Cijambe sub-district with an altitude of 365 meters above sea level. This place is a pineapple leaf processing area that starts from sorting the leaves to become ready-to-sell goods in the form of a bundle of fibre weighing $1 \mathrm{~kg}$. PALF processing in Subang is on a micro-scale with constantly evolving tools and methods. The manufacturing process is still nonexistent, so the data used comes from the microeconomic activities of PALF processing. There are lots of aspects within the LCA study. However, this study focuses only on its impact on air pollution through carbon footprint calculation on its operation elements. The carbon footprint calculation uses the data throughout the emissions of diesel engines that use diesel as fuel, both in terms of transportation and engine requirements.

The PALF processing process into paper (nonwoven textiles) starting from the cradle to the gate can be seen in Figure 2.
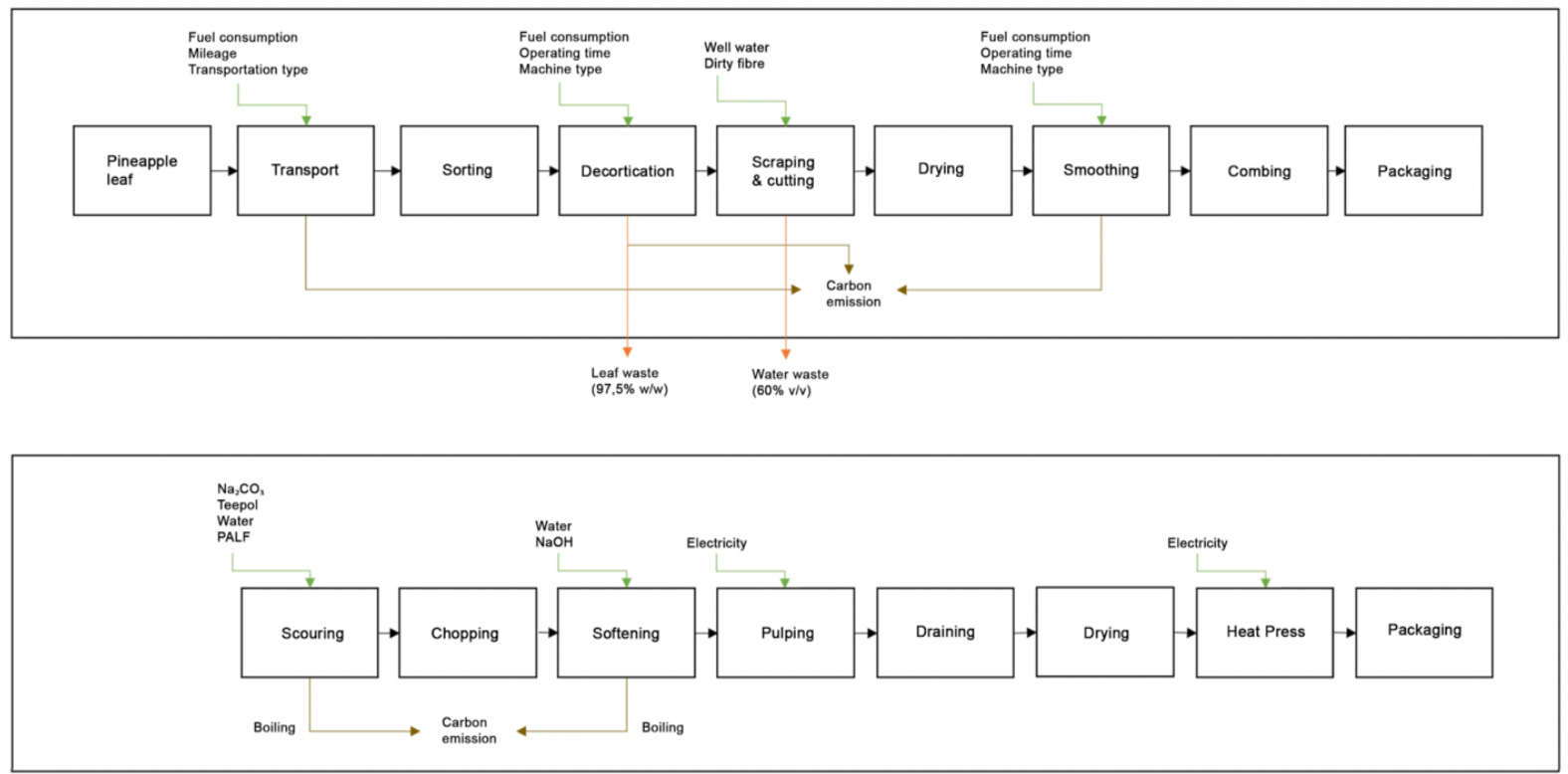

Figure 2 PALF cradle-to-gate processing production process.

[13]. Determination of geographical system boundary in Subang Regency with the research location located
Based on the flow of the PALF processing production process, the potential carbon emissions 
come from transport, extraction, refining, scouring, softening and electricity. Transport is calculated based on diesel by a 125 PS medium-sized truck with fuel consumption of $4.93 \mathrm{~km} / \mathrm{L}$ diesel with a mileage of 3.4 $\mathrm{km}$. There are three classifications for Pineapple leaves: short $(65-75 \mathrm{~cm})$, medium $(75-85 \mathrm{~cm})$, and long (above $85 \mathrm{~cm}$ ). The leaves used are leaves in the middle of pineapple growth (D-Leaves and C-Leaves) due to their solid quality and uniform length and reasons for worker safety on the machine. In the PALF processing operation, there are five diesel-fueled engines with a power of 7HP located in open and closed areas emitting pollutions from the diesel combustion with an average consumption of 3 $\mathrm{L} / \mathrm{machine}$ /day. Both have the same fuel with different uses. Thus, the carbon emission value calculation of $2.68 \mathrm{~kg} \mathrm{CO} / \mathrm{L}$ Solar is used for 7.5 hours of the total operation. The operating time separates into two types based on the work function, namely extraction and refining, by dividing according to a 1:40 ratio (fibre: leaf).

The machine used does not require a power supply and other manual processing so that no variable electricity demand as an input. The drying process

Table 2. Carbon footprint calculation of $12.5 \mathrm{~kg}$ PALF

\begin{tabular}{|c|c|c|c|c|c|c|c|}
\hline No. & Process & Items & Specification & Consumption & $\begin{array}{l}\text { Amount } \\
\text { of work }\end{array}$ & $\begin{array}{l}\text { Total Emission } \\
\text { ( } \mathrm{Kg} \mathrm{CO}_{2} \text { eq.) }\end{array}$ & References \\
\hline$A$ & \multicolumn{7}{|c|}{ Fibre Production } \\
\hline 1 & Harvesting & - & - & - & - & - & - \\
\hline 2 & Transportation & Diesel & 6-wheel truck & $\begin{array}{l}4.93 \mathrm{~km} / \mathrm{L} \\
\text { solar }\end{array}$ & $3.4 \mathrm{~km}$ & 1.847257 & Exeter.ac.uk \\
\hline 3 & Sorting & - & & - & - & - & - \\
\hline 4 & Decortication & Diesel & $\begin{array}{l}5 \text { units } \\
\text { decorticator } \\
@ 1250 \text { rpm }\end{array}$ & 0.4 L/unit/hrs & $7.5 \mathrm{hrs}$ & 39.195 & Exeter.ac.uk \\
\hline 5 & $\begin{array}{l}\text { Scraping \& } \\
\text { Cutting }\end{array}$ & - & & - & - & - & - \\
\hline 6 & Drying & - & & - & - & - & - \\
\hline 7 & Smoothing & Diesel & $\begin{array}{l}5 \text { units } \\
\text { decorticator } \\
@ 1250 \text { rpm }\end{array}$ & $0.4 \mathrm{~L} / \mathrm{unit} / \mathrm{hrs}$ & $0.19 \mathrm{hrs}$ & 1.005 & Exeter.ac.uk \\
\hline 8 & Combing & - & - & - & - & - & - \\
\hline 9 & Packaging & - & - & - & - & - & - \\
\hline B & \multicolumn{7}{|c|}{ Paper Production } \\
\hline 1 & Scouring & $\begin{array}{l}\mathrm{Na}_{2} \mathrm{CO}_{3} \\
\text { Teepol, }\end{array}$ & $10 \% \mathrm{w} / \mathrm{w}$ & $\begin{array}{l}1.84 \quad \mathrm{~kg} \\
\mathrm{CO}_{2} \text { eq. } / \mathrm{kg}\end{array}$ & $\begin{array}{l}0,1229 \mathrm{~kg} \\
\mathrm{Na}_{2} \mathrm{CO}_{3}\end{array}$ & 0.226136 & $\begin{array}{l}\text { Prashantsinh, } \\
\text { M. et al., } 2015\end{array}$ \\
\hline 2 & Chopping & - & - & - & - & - & - \\
\hline 3 & Softening & $\mathrm{NaOH}$ & 1:3 water & $\begin{array}{l}0.6329 \mathrm{~kg} \\
\mathrm{CO}_{2} \text { eq./kg }\end{array}$ & $0.3 \mathrm{~kg}$ & 0.190 & $\begin{array}{l}\text { Thannimala } \\
\text { y, L. et al., } \\
2013\end{array}$ \\
\hline 4 & Pulping & Blender & $250 \mathrm{~W}$ & $4.16 \mathrm{kWh}$ & $1 \mathrm{~min}$ & 0.293 & Epa.gov \\
\hline 5 & Draining & - & - & - & - & - & - \\
\hline 6 & Drying & - & - & - & - & - & - \\
\hline 7 & Finishing & Heat press & $2000 \mathrm{~W}$ & 166.67 kWh & $5 \mathrm{~min}$ & 11.812 & Epa.gov \\
\hline 8 & Packaging & - & - & - & - & - & - \\
\hline \multicolumn{6}{|c|}{ Total } & \multicolumn{2}{|l|}{55.394763} \\
\hline
\end{tabular}


uses open drying with the help of the sun's heat. Processing pineapple leaves into fibre require 150 $\mathrm{L} /$ day of water. Water footprints are not in the scope of the study, so water demand is considered as data outside the boundary. PALF production capacity has only reached a ratio of $2.5 \%$ or $2.5 \mathrm{~kg}$ PALF from 100 $\mathrm{kg}$ of processed leaves until now. In one day, this place can process up to $500 \mathrm{~kg}$ of pineapple leaves. By comparing the number of processed leaves with the resulting fibre, the machine work on extraction was 7.31 hours/day and machine work on refining was 0.18 hours/day. As much as $97.5 \%$ of the waste generated from the decortication process is leaf flesh which primarily consists of chlorophyll and has no significant impact on the environment, leaving it outside the study boundary. Another waste is excess entangled PALF with a daily volume of about 5 $\mathrm{kg} /$ day. There has not been any utilization, also leaving it outside the study boundary.

After processing into a ready-to-use fibre, the fibre entered the pulping stage. From this stage, elements that can contribute to air carbon emissions are boiling and electricity. This method uses a scouring step, which is cleaning the fibre from dirt that may be carried away and then softening it through boiling with the addition of $\mathrm{NaOH}$. In the flow of the papermaking process, the calculations use a similar method, namely the multiplication between boiling teepol, $\mathrm{Na}_{2} \mathrm{CO}_{3}, \mathrm{NaOH}$, and water with the inventory obtained. The scouring process takes 122.9 grams of teepol, which is boiled in 2.5 liters of water for 40 minutes, to process 1 kilogram of PALF. The following softening process uses 300 grams of caustic soda boiled in 2.5 liters of water. Pulp from $1 \mathrm{~kg}$ PALF can produce 29 sheets of A4 paper or six sheets of A2. The functional unit is defined as $1 \mathrm{~m}^{2}$ of nonwoven fabric material ready to be used as a primary product. Below are the overall results of the calculation of PALF's carbon footprint.

\section{CONCLUSION}

Comparison of Life Cycle Assessment of PPE polypropylene and nonwoven PALF in this study focuses on carbon footprint analysis and is limited to the scope of cradle-to-gate. $1 \mathrm{~kg}$ of pineapple leaf fibre with a specific gravity of $0.8822 \mathrm{~g} / \mathrm{cm}^{3}$ can be processed into $1.5 \mathrm{~m}^{2}$ of material with a thickness of $381.5 \mu \mathrm{m}$ with a tensile strength of $2.21 \mathrm{kN} / \mathrm{m}$. Thus, to process $1 \mathrm{~m}^{2}$ of material in the home industry produces $4.43 \mathrm{~kg}$ of $\mathrm{CO}_{2}$ eq emissions. Time of natural degradation of the total material for 21 days. Calculations were also carried out on polypropylene fibre (PP) using secondary data using the same procedure and obtained carbon emissions of $4.769 \mathrm{~kg}$ $\mathrm{CO} 2$ to produce a material area of $27 \mathrm{~m}^{2}$. Thus, to process $1 \mathrm{~m}^{2}$ of material on an industrial scale, 0.176 $\mathrm{kg} \mathrm{CO} 2$ is produced with a tensile strength ranging from $50-600 \mathrm{mPa}$.

The study results show that the production of $1 \mathrm{~m}^{2}$ nonwoven textiles made from PALF still has a larger carbon footprint, 13 times more than fabricated PP raw materials, but this may be because PP is massproduced. However, when viewed from the required degradation time, the raw material of pineapple leaf fibre is much better, which is 347 to 521 times better. The adverse effects produced by PP become very significant after the gate stage, one of which is because it takes 20-30 years to degrade naturally. In addition, the burning of PP waste using an incinerator, which is currently considered the most effective, produces harmful gas particles, including greenhouse gas (GHG) emissions that have an impact on Global Warming Potential (GWP), as well as dioxin and furan gases that are harmful to health.

The study shows that there is potential to develop nonwoven textiles from PALF raw materials, given the ongoing pandemic conditions, to continue to meet daily human needs and protect the environment from these aftermath human needs. The advantage of this LCA method is that it can provide complete information on the product, process, or service. LCA's can calculate the production or consumption of resources such as energy or carbon emissions regardless of where the process is located or converted from one form to another. The calculation results can be used to identify the major impacts on the environment and see opportunities or alternatives that are more efficient. However, LCA has several disadvantages: inventory data is difficult to obtain; it has a comprehensive scope; it can be time-consuming and costly to collect data; and it is very specific and often cannot be transferred to similar operations.

\section{SUGGESTION}

The issue of sustainability is currently in the spotlight; this LCA method can be applied at the level of small and medium-sized enterprises and will be very much needed in Indonesia. Further research is still needed for certain criteria such as LCA related to other variables, eligibility to be used as medical PPE, good coating types, and the development of scaled-up production methods. 


\section{AUTHORS' CONTRIBUTIONS}

Both of PRS and $\mathrm{AB}$ carried out the experiments, analysis of data, and drafted the manuscript. All of the authors read and approved the final manuscript.

\section{ACKNOWLEDGMENTS}

This research was funded by the 2021 PPMI grant from Institut Teknologi Bandung, and is an output of the Craft and Tradition Research Group. The authors would like to thank Mr. Alan Syahroni of Alfiber for allowing a visit to his workshop in June 2021.

\section{REFERENCES}

[1] Who.int. 2020. Shortage of personal protective equipment endangering health workers worldwide. [online] Available at: $<$ https://www.who.int/news/item/03-03-2020shortage-of-personal-protective-equipmentendangering-health-workers-worldwide> [Accessed 7 July 2021].

[2] H. Kumar, A. Azad, A. Gupta, J. Sharma, H. Bherwani, N. Labhsetwar, and R. Kumar, COVID-19 Creating another problem? Sustainable solution for PPE disposal through LCA approach, Environment, Development and Sustainability, Springer, Berlin, Heidelberg, 2020 , pp. 9418-9432. DOI: $10.1007 / \mathrm{s} 10668-020-$ 01033-0

[3] S. Sangkham, Face mask and medical waste disposal during the novel COVID-19 pandemic in Asia. Case Studies in Chemical and Environmental Engineering, 2020 Oct, pp.100052. DOI: $10.1016 /$ j.cscee.2020.100052

[4] A. Tripathi, V. Tyagi, V. Vivekanand, P. Bose, S. Suthar, Challenges, opportunities, and progress in solid waste management during COVID-19 pandemic, vol 2, Case Studies in Chemical and Environmental Engineering, 2020 Nov, pp.10223. DOI: https://doi.org/10.1016/j.cscee.2020.100060

[5] C. Nugraha, Tinjauan Kebijakan Pengelolaan Limbah Medis Infeksius Penanganan Corona Virus Disease 2019 (Covid-19), vol.4, Jurnal untuk Masyarakat Sehat, 2020 Oct, pp.2. DOI: https://doi.org/10.52643/jukmas.v4i2.1004

[6] R. Cordova, I. Nurhati, E. Riani, Nurhasanah, Y. Iswari, Unprecedented plastic-made personal protective equipment (PPE) debris in river outlets into Jakarta Bay during COVID-19 pandemic, vol. 268, Chemosphere, 2021. DOI: https://doi.org/10.1016/j.chemosphere.2020.129 $\underline{360}$

[7] Y. Ruslinda, R. Aziz, F. Putri, Analysis of Household Solid Waste Generation and Composition During The Covid-19 Pandemic in Padang City, Indonesia, vol. 4, Indonesian Journal of Environmental Management and Sustainability, 2020 Dec, pp. 4. DOI: https://doi.org/10.26554/ijems.2020.4.4.116-124

[8] R. K. Ganguly, S. K. Chakraborty, Integrated approach in municipal solid waste management in COVID-19 pandemic: Perspectives of a developing country like India in a global scenario, vol. 3, Case Studies in Chemical and Environmental Engineering, 2021. DOI: https://doi.org/10.1016/j.cscee.2021.100087

[9] Y. Park, K. Kim, S. Roth, S. Beck, W. Kang, C. Tayag, M. Grifin, This brief examines the global shortage of the personal protective equipment (PPE) needed to tackle COVID-19 and suggests policy implications. Asian Development Bank, 2020.

DOI:

http://dx.doi.org/10.22617/BRF200128-2

[10] N. Parashar, S. Hait, Plastics in the time of COVID-19 pandemic: Protector or polluter?, The Science of the total environment, 2021 Mar, vol. 759. DOI: https://doi.org/10.1016/j.scitotenv.2020.144274

[11] International Standard Organisation (ISO), ISO 14040. Environmental Management - Life Cycle Assessment - Principles and Framework. International Organization for Standardization (ISO), 1997.

[12] L. Thannimalay, S. Yusoff, N. Zawawi, Life Cycle Assessment of Sodium Hydroxide, vol. 7(2), Australian Journal of Basic and Applied Sciences, 2013, pp. 421-431.

[13] W. Klopffer, Publishing scientific articles with special reference to LCA and related topics, vol. 12, The International Journal of Life Cycle Assessment, 2007, pp. 71-76. DOI: http://dx.doi.org/10.1065/lca2007.01.306

[14] H. Yasar, World of plastics, vol. 1, Ankara TMMOB Mech. Eng. Publ., 2004, pp. 59-63.

[15] M. Harussani, S. Sapuan, U. Rashid, and A. Khalina, Development and Characterization of Polypropylene Waste from Personal Protective Equipment (PPE)-Derived Char-Filled Sugar 
Palm Starch Biocomposite Briquettes, vol. 13, Polymers, 2021, pp. 1707. DOI: http://dx.doi.org/10.3390/polym13111707

[16] Opalene-PP, Polypropylene (PP), Material Safety Data Sheet, 2016.

[17] A.R Jiniputri, S.I. Sakina, A. Oktaviana, Exploration of Natural Fibre Processing of Smooth Cayenne Variety Pineapple Leaves with Pulping and Paper Making Techniques, in Proc. of Seminar Nasional Tekstil, 2020.

[18] F. Fathurohman, Peningkatan Kesejahteraan Masyarakat melalui Peningkatan Nilai Produk di Kabupaten Subang, Sakai Sambayan Jurnal Pengabdian kepada Masyarakat, 2020, pp. 95-98. DOI: http://dx.doi.org/10.23960/jss.v4i2.155

[19] N. Diana, Pemanfaatan Daun Nanas (Ananas Comosus) sebagai Adsorben Logam Berat (Penelitian dan Pengembangan Format Lembar Kerja Kimia Terapan Berbasis Saintifik), UIN Sunan Gunung Djati, Bandung, 2014. http://digilib.uinsgd.ac.id/id/eprint/715

[20] J. Botella, A. Cavallaro, and C. Cazzonelli, Towards the production of transgenic pineapple to control flowering and ripening, Acta Horticulturae, 2000, pp. 529. DOI:

https://doi.org/10.17660/ActaHortic.2000.529.1 3

[21] E. Malezieux, Global network for pineapple research, vol. 529, Acta Horticulturae, 2000, pp. $35-47$.

DOI: https://doi.org/10.17660/ActaHortic.2000.529.2

[22] A. Singha, V. Thakur, Mechanical, morphological, and thermal characterization of compression-molded polymer biocomposites, vol. 15, International Journal of Polymer Analysis and Characterization, 2010, pp. 87-97. DOI:

http://dx.doi.org/10.1080/10236660903474506

[23] M. Asim, K. Abdan, M. Jawaid, M. Nasir, Z. Dashtizadeh, R. Ishak, and E. Hoque, A Review on Pineapple Leaves Fibre and Its Composites, International Journal of Polymer Science, 2015.

DOI: https://doi.org/10.1155/2015/950567

[24] N. Lopattananon, K. Panawarangkul, K. Sahakaro, and B. Ellis, Performance of pineapple leaf fibre-natural rubber composites: the effect of fibre surface treatments, vol. 102(2), Journal of Applied Polymer Science, 2006, pp. 1974-1984. DOI: https://doi.org/10.1002/app.24584

[25] Y. G. T. Girijappa, S. M. Rangappa, J. Parameswaranpillai, and S. Siengchin, Natural Fibres as Sustainable and Renewable Resource for Development of Eco-Friendly Composites: A Comprehensive Review, vol. 6(226), Biodegradable Matrices and Composites, 2019.

DOI: https://doi.org/10.3389/fmats.2019.00226

[26] H. P. S. A Khalil, M. Alwani, and A. Omar, Distribution, and cell wall structure of malaysian plant waste fibres, vol. 1, BioResources. 2006, pp. 220-232.

[27] A. V. Tran, Chemical analysis and pulping study of pineapple crown leaves, vol. 24, Industrial Crops and Products, 2006, no. 1, pp. 66-74. DOI: https://doi.org/10.1016/j.indcrop.2006.03.003

[28] D. Gope, A. Gope, P. C. Gope, Mask material: challenges and virucidal properties as an effective solution against coronavirus SARSCoV-2, vol. 1, Open Health, 2020, pp. 37-50. DOI: http://dx.doi.org/10.1515/openhe-2020$\underline{0004}$

[29] E. Lin, A. Howell, Wettable SMS Material for Personal Protective Equipment Applications, 16/104629, 20-Feb-2020.

[30] R. Samal, and M. Ray, Effect of chemical modifications on FTIR spectra. II. Physicochemical behavior of pineapple leaf fibre (PALF), vol 64(11), Journal of Applied Polymer Science, 1997, pp. 2119-2125.

[31] S. Sinha, A. Aman, R. Rajan, The Significance of 'D' Leaf in Pineapple. Biomolecular Reports, 2018.

[32] S.G. Wiryadinata, I. Indriani, S.I. Sakina. Biodegradable PPE Made of Pineapple Fibre Paper, submitted for publication.

[33] J. Korol, D. Korol, and M. Pichlak, Expansion of environmental impact assessment for ecoefficiency evaluation of biocomposites for industrial application, vol. 113, The Journal of Cleaner Production, 2016, pp. 144-152. DOI: http://dx.doi.org/10.1016/j.jclepro.2015.11.101

[34] S. Nuryati, Penggunaan Bahan Bakar Minyak terhadap Kecepatan Kendaraan dan Nilai Waktu 
Perjalanan di Wilayah Kota Bekasi, vol. 5(1), Jurnal Bentang, 2017, pp. 45-61.

[35] People.exeter.ac.uk. Calculation of $\mathrm{CO} 2$ emissions. [online] Available at: $<$ https://people.exeter.ac.uk/TWDavies/energy conversion/Calculation $\% 20$ of $\% 20 \mathrm{CO} 2 \% 20 \mathrm{emis}$ sions $\% 20$ from $\% 20$ fuels.htm $>$ [Accessed 21 June 2021].

[36] M. Mainnah. 2021. Sifat Fisik dan Mekanik Kombinasi Serat Daun Nanas (Ananas sp.) dan Kitosan untuk Material Alat Penangkapan Ikan. [online] Available at: Repository.ipb.ac.id. Available from: $<$ http://repository.ipb.ac.id/handle/123456789/8 5326> [Accessed 28 June 2021].

[37] E. Richaud, B. Fayolle, and P. Davies, Tensile properties of polypropylene fibres, Handbook of Properties of Textile and Technical Fibres, 2018, pp. 515-543. DOI: https://doi.org/10.1533/9781845696801.2.315 